\title{
Effect of albumin and free calcium concentrations on calcium binding in vitro
}

\author{
ANATOLE BESARAB, AURORA DEGUZMAN, JOHN W SWANSON \\ From the Departments of Medicine and Physiology, Thomas Jefferson University, Philadelphia, USA
}

SUMMARY In vivo equilibrium dialysis studies were performed to define further the characteristics of calcium binding to bovine albumin. The concentration range for albumin ( 1 to $9 \mathrm{~g} / \mathrm{dl})$ as well as ultrafilterable calcium $(0.5$ to $2.5 \mathrm{mM})$ studied encompassed those that might be ordinarily encountered in most clinical situations. Major differences in the regressions of total calcium on ultrafilterable calcium occurred at albumin concentrations of 1,2 , and $9 \mathrm{~g} / \mathrm{dl}$ but only small differences at albumin concentrations between 3,5 and $7 \mathrm{~g} / \mathrm{dl}$. When albumin concentration was kept constant, the amount of calcium bound to albumin varied directly with ultrafilterable calcium. At any constant ultrafilterable calcium concentration albumin bound calcium varied inversely with the albumin concentrations when albumin was greater than $3 \mathrm{~g} / \mathrm{dl}$. Analysis of the data to determine association constants and molar calcium to albumin binding ratios showed that both parameters were dependent on the absolute albumin concentrations. Our results indicate that calcium binding to albumin is a complex process characterised by multiple binding sites whose affinity and binding capacity are variable. These properties suggest that correction of total serum calcium using clinical formulations with fixed calcium to albumin binding ratios may be inappropriate, particularly in hypoalbuminaemic states.

Calcium in serum exists in three separate forms; ${ }^{12}$ ionised $\left(\mathrm{Ca}^{2+}\right)$, complexed $\left(\mathrm{Ca}_{\mathrm{R}}\right)$, and protein bound (CaPr), but only the free or ionised calcium is physiologically important. With changes in albumin concentration occurring during alterations in posture, ${ }^{3}$ venous stasis, ${ }^{4}$ or during disease processes, ${ }^{45}$ concomitant changes in total calcium (Сат) are known to occur but the free calcium is thought not to change. Thus a variety of formulations have been proposed using either total serum protein, $3^{3-8}$ or serum albumin 46910 concentrations to correct the total calcium for the effect of such changes in protein. Other approaches include both albumin and globulin concentrations. ${ }^{11}$ Only one algorithm, that developed by McLean and Hastings, ${ }^{1}$ however, interrelates the total calcium $\left(\mathrm{Ca}_{\mathbf{T}}\right)$ to the concentrations of ionised calcium and total protein.

The original formulation by McLean and Hastings described the association of calcium and any protein by the following relation:

$$
\mathrm{K}_{\mathrm{A}}=\left[\mathrm{CaPr}^{-\mathbf{n}}\right] /\left[\mathrm{Ca}^{2+}\right]\left[\mathrm{Pr}^{-\mathbf{n}-2}\right]
$$

where $K_{A}$ is the equilibrium association constant.
This mass law equation predicts that protein bound calcium, $\mathrm{CaPr}^{-n}$, should vary directly with $\mathrm{Ca}^{2+}$ at any specified constant concentration of a particular protein. Both in vitro ${ }^{12}$ and in vivo studies in rats ${ }^{13}$ support this prediction. Recently, some studies have indicated, however, that $\mathbf{K}_{\mathrm{A}}$ characterising calcium binding to albumin (the major calcium binding serum protein) might not be a true constant. ${ }^{14}$ Examination of the original data of Weir and Hastings ${ }^{15}$ also indicates that $K_{A}$ might vary significantly with albumin concentrations. A range of albumin and calcium concentrations comparable to that frequently found in clinical situations was not investigated in either study. The importance of variation in $\mathrm{K}_{\mathrm{A}}$ in the clinical application of various formulations is unknown but many of them contain the inherent assumption that $\mathrm{K}_{\mathrm{A}}$ is a true constant. ${ }^{16}$ In this study we attempted to measure in vitro the changes in protein bound and total calcium concentrations over a range of albumin concentrationencompassing hypoalbuminaemic to hyperalbumisn aemic states and over a range of free calcium concentrations equivalent to severe hypocalcaemia or hypercalcaemia. These data could then be used as a reference frame for clinical studies. 
Methods

\section{REAGENTS}

All chemical reagents used were analytical grade. Bovine serum albumin (BSA), fraction $V$, was obtained from Armour and shown to migrate as a single homogeneous peak by electrophoresis and was greater than $98 \%$ protein by ash analysis. Double glass-distilled water was used to prepare all solutions.

\section{EQUILIBRIUM DIALYSIS}

Albumin solutions were prepared and dialysis performed to measure the effect of two major variables: (i) at any constant albumin concentration, dialysate $\mathrm{Ca}^{2+}$ was varied from 0.5 to $2.5 \mathrm{mM}$; (ii) at a constant dialysate $\mathrm{Ca}^{2+}$ concentration, albumin concentration was varied from approximately 1.0 to $9.0 \mathrm{~g} / \mathrm{dl}$. The composition and therefore ionic strength of the dialysate buffer with respect to all other components was kept constant.

Batches of BSA $(200 \mathrm{ml})$ containing approximately $1 \cdot 1,2 \cdot 2,3 \cdot 3,5 \cdot 5,7.6$ and $9 \cdot 8 \mathrm{~g} / \mathrm{dl}(\mathrm{wt} / \mathrm{vol})$ were dissolved in Krebs-Henseleit bicarbonate buffer (KHB) which contained in millimoles/l: $\mathrm{Na}^{+} 143, \mathrm{~K}^{+} 4 \cdot 5$, $\mathrm{Ca}^{2+} 0 \cdot 5, \mathrm{Mg}^{2+} 1 \cdot 2$, phosphate $1 \cdot 2$, sulphate $1 \cdot 2$, $\mathrm{Cl}-122, \mathrm{HCO}_{3}-25$. The albumin concentrations of these batches were initially set $10 \%$ higher than those ultimately desired to compensate for protein losses and oncotic flow of $\mathrm{H}_{2} \mathrm{O}$ into the cellophane bags during dialysis. Loss of albumin from the dialysis bags was always less than $1 \%$ of the original amount. The effect to dilute protein concentration during dialysis was greater than the concentrating effect during subsequent ultrafiltration upon terminating dialysis. The buffer media was gassed with 95:5 $\left(\mathrm{O}_{2}: \mathrm{CO}_{2}\right)$ before dissolving the $\mathrm{BSA}$ at varying concentrations. All albumin batches were filtered through $0.2 \mu \mathrm{m}$ (Millipore) filters, then placed in cellophane bags and dialysed against a tenfold volume of $0.5 \mathrm{~m} M \mathrm{KHB}$-buffer to remove dialysable $\mathrm{Ca}^{2+}$ chelators. This dialysis and all subsequent dialysis steps were performed using sterile techniques. The dialysate was continuously gassed to maintain constant $\mathrm{pH}$ and was changed at 12 hours.

After this initial dialysis, the batches of BSA media with varying albumin concentrations were divided into aliquots and these were further dialysed at $37^{\circ} \mathrm{C}$ against $\mathrm{KHB}$-buffer whose calcium concentrations was varied from 0.5 to $2.5 \mathrm{mM}$. The entire procedure was performed in duplicate for each $\mathrm{Ca}^{2+}$ and albumin concentration. Again, the dialysates were changed at 12 hours and continuously gassed with 95:5 $\left(\mathrm{O}_{2}: \mathrm{CO}_{2}\right)$. The dialysate to albumin media volume ratio was 12:1. Preliminary studies demonstrated that equilibrium was achieved within 12 hours.
After 24 hours, 15 to $18 \mathrm{ml}$ samples of the BSA media were removed anaerobically from the dialysis bags by puncturing with a needle and syringe. Cultures of the BSA media were negative; the dialysate had less than 5 colonies/ml of Psaeruginosa. Ultrafiltrate was obtained by pressure filtration through amicon CR 25 membrane filters which retained substances greater than 25000 daltons. Pressure filtration was carried out in a closed syringe system after warming the syringe and its contents to $36-7^{\circ} \mathrm{C}$. Ultrafiltrability of pure $\mathrm{CaCl}_{2}$ or calcium dialysate buffer solutions was 0.99 and 0.98 respectively. With protein solutions, a small error in measuring true $\mathrm{Ca}_{u}$ can be induced by the process itself since ultrafiltration may alter retentate $\mathrm{Ca}^{2+}$ and protein concentrations. Limiting the degree of ultrafiltration reduces this effect. The volume of ultrafiltrate was therefore kept to less than $5 \%$ of the initial sample volume to minimise alterations in sample calcium and protein concentrations. The first $0.5 \mathrm{ml}$ of ultrafiltrate formed (representing the dead space) was discarded and $\mathrm{Ca}_{\text {up }}$ measured on the next two 50 to $100 \mu \mathrm{l}$ aliquots formed. There was no significant difference in $\mathrm{Ca}_{\mathrm{u}}$ between the first and second aliquot. The $\mathrm{pH}$ of the retentate was compared to that of the original solution. The initial $\mathrm{pH}$ averaged $7.44 \pm 0.02$ and did not change during ultrafiltration $(\triangle \mathrm{pH}=0.2 \pm 0.02)$. After ultraz filtration the final retentate albumin concentrations were 1.04, 2.02, 3.05, 4.97, 6.93, and $8.96 \mathrm{~g} / \mathrm{dl}$ and are reported as the integer values.

\section{ANALYTICAL METHODS}

The $\mathrm{pH}$ was measured with an IL digital $\mathrm{pH}$ meter, model 313 , with reproducibility of duplicate determinations of $0.01 \mathrm{pH}$ units. The retentate total and ultrafiltrate calcium concentrations were measured by atomic absorption spectrophotometry (Perkin Elmer, model 353), overall coefficient of variations of $2 \cdot 1 \%$. The retentate protein concentrations were measured by the Biuret reaction. Replicate determinations of total protein were within 0.05 to $0.2 \mathrm{~g} / \mathrm{dl}$. Ionised calcium in selected experiments was measured with the Orion SS 20 system which had a coefficient of variation of $2.6 \%$.

\section{CALCULATIONS}

Total calcium $\left(\mathrm{Ca}_{\mathrm{T}}\right)$, ultrafilterable calcium $\left(\mathrm{Ca}_{\mathrm{uf}}\right)$, or retentate ionised calcium $\left(\mathrm{Ca}^{2+}\right)$ were measured directly. The following definitions were used.

[] represents the molar concentration of a substance.

$\mathrm{Alb}^{-2}$ is any calcium binding site on albumin.

$\mathrm{CaAlb}$ is any combination of calcium with albumin.

tAlb is total albumin. 
$\mathrm{n}=\mathrm{CaAlb} / \mathrm{tAlb}$, sites actually bound per albumin molecule.

$\mathbf{N}=$ total sites available on any albumin molecule. $\mathrm{K}_{\mathrm{A}}=$ equilibrium association constant.

$$
\mathrm{K}_{\mathrm{A}}=\frac{[\mathrm{CaAlb}]}{\left[\mathrm{Ca}^{2+}\right]\left[\mathrm{Alb}^{2-}\right]}
$$

To determine the kinetics of calcium binding - that is, the association constant and total numbers of binding sites, two techniques can be used. The first is the equation of McLean and Hastings, but this requires a value for a conversion factor which gives the concentration of sites available for binding in millimoles per litre when the concentration of protein is given in $\mathrm{g} / \mathrm{dl}$. This correction factor incorporates the total sites available for calcium ions per albumin molecule at high calcium concentration. The published values for $\mathbf{N}$ range from 8 based on the work of Carr, ${ }^{12}$ to 12 based on the work of Pederson ${ }^{17}$ to 19 or greater obtained by Anderson. ${ }^{14} \mathrm{We}$ used the alternative method and constructed a Scatchard plot.

The various parameters were calculated in the following manner

$$
\begin{array}{cc}
{[\mathrm{CaAlb}]=\left[\mathrm{Ca}_{T}\right]-\left[\mathrm{Cauf}_{\mathrm{u}}\right]} & \mathrm{Eq} \mathrm{(2)} \\
\mathrm{N}[\mathrm{tAlb}]=[\mathrm{CaAlb}]+\left[\mathrm{Alb}^{2-}\right] & \mathrm{Eq}(3)
\end{array}
$$

Equations (1) and (3) are combined and rearranged to give

$$
\frac{n}{\left[\mathrm{Ca}^{2+}\right]}=-K_{A}(n-N)
$$

The last equation has a form suitable for a Scatchard plot where $n / \mathrm{Ca}^{2+}$ is plotted against $n$ (equivalent to plotting bound/free against bound). The slope is equal to $-K_{A}$ and the intercept on the abscissa is equal to $\mathrm{N}$, the total number of binding sites per albumin molecule. Cauf was known in all experiments but $\mathrm{Ca}^{2+}$ in only some of the experiments. The Scatchard plots were thus constructed using $\mathrm{n} / \mathrm{Cauf}$ on the abscissa since chelated calcium usually represented a small fraction of total calcium and the difference between $\mathrm{Ca}^{2+}$ and $\mathrm{Ca}_{u}$ was small (vida infra).

In addition we analysed the data by the convention used clinically-that is, protein bound calcium was calculated (Eq. 2 above) and then factored by the retentate albumin concentration to yield $\mathrm{mg}$ of calcium bound per $\mathrm{g}$ albumin in the retentate solution. This method is not rigorous and cannot yield values for $\mathrm{K}_{\mathrm{A}}$ or $\mathrm{N}$ since the latter requires expression of data in molar units.

\section{STATISTICS}

The least-squares method was used to develop linear regressions between two variables. The varianceratio test was used to evaluate differences between regressions.

\section{Results}

All results in Table 1 represent the mean of at least four measurements for each parameter except ionised calcium which was measured in duplicate. At all albumin concentrations, $\mathrm{Ca}_{\mathrm{T}}$ increased almost linearly with $\mathrm{Ca}_{\text {uf }}$ as shown in Fig. 1. Only small differences in $\mathrm{Ca}_{\mathrm{T}}$ were noted at any $\mathrm{Ca}_{\mathrm{u}}$ in the range of albumin concentrations from 3 to $7 \mathrm{~g} / \mathrm{dl}$. At the lower albumin concentrations of 1 and $2 \mathrm{~g} / \mathrm{dl}$, the curves were shifted to the right, that is, a smaller fraction of total calcium was bound (Table 1). The percent of total calcium bound to albumin increased with ultrafilterable calcium at albumin concentrations of 1,2 and $9 \mathrm{~g} / \mathrm{dl}$ but decreased slightly at the intermediate albumin concentrations of 3,5 , and $7 \mathrm{~g} / \mathrm{dl}$ as shown in Table 1 . Over the range of calcium and albumin concentrations studied, no saturation of calcium binding sites was noted.

The above results suggested that changes in protein binding characteristics could occur with variation in albumin concentration. An initial evaluation was made by replotting the data in Fig. 1 using clinical conventions. At any specified constant Cauf value, the protein bound calcium ( $\mathrm{Ca}_{\mathrm{T}}-\mathrm{Caus}$ ) was calculated at each albumin concentration. The protein bound calcium was then divided by the retentate albumin concentration to yield the milligrams of calcium bound per gram of albumin. This was then plotted against albumin concentration. The procedure was then repeated at different Cauf concentrations from 2 to $6 \mathrm{mg} / \mathrm{dl}$. As shown in Fig. 2 these relations are extremely complex. Expressed in this way, the amount of $\mathrm{Ca}$ bound/g albumin is influenced both by the albumin and ultrafilterable calcium concentrations. The important observation is that the amount of calcium bound per gram of albumin decreases as albumin increases from 3 to $9 \mathrm{~g} / \mathrm{l}$ when $\mathrm{Ca}_{u}$ is held constant. The change in protein binding with albumin concentration is shown in another way in Fig. 3. Linear regression curves for the data in Fig. 1 were determined. At any constant Cauf, the total calcium was calculated and plotted against albumin concentration. At a $\mathrm{Ca}_{u}$ of $5 \cdot 5$, a marked change in slope, from 1.52 to $0.40 \mathrm{mg}$ calcium/gram albumin, occurs at $3 \mathrm{~g} / \mathrm{dl}$ albumin. The latter slope is virtually identical to the regression coefficient for $\mathrm{Ca}_{\mathrm{T}}$ on albumin obtained by Ljunghall et $a l^{9}$ in vivo in a cohort of 2000 normal men. As Caut was decreased, the slope of CaT on albumin at low albumin concentrations decreased. These results suggest the presence of at least two calcium albumin binding sites with varying affinities or capacities, or both.

This was confirmed by using Scatchard plot analysis (Fig. 4). The slopes of the inverse relations 
Table 1 Experimental data for calcium binding to bovine serum albumin

\begin{tabular}{|c|c|c|c|c|c|}
\hline$B S A(g / d l)$ & $C a_{T}(m M)$ & $C a_{u f}(m M)$ & $\mathrm{Ca}^{2+}(m \mathrm{M})$ & $\mathrm{CaPr}^{-n}(m M)$ & Percent Ca bound \\
\hline \multirow{5}{*}{1} & 0.50 & 0.43 & 0.41 & 0.07 & 14 \\
\hline & 1.06 & 0.91 & $0 \cdot 84$ & $0 \cdot 15$ & 14 \\
\hline & 1.54 & 1.27 & $1 \cdot 20$ & $0 \cdot 27$ & $17 \cdot 5$ \\
\hline & $2 \cdot 29$ & 1.68 & 1.59 & 0.61 & 27 \\
\hline & $3 \cdot 08$ & $2 \cdot 18$ & 1.95 & 0.90 & 29 \\
\hline \multirow{5}{*}{2} & 0.53 & 0.46 & & $0 \cdot 17$ & 27 \\
\hline & 1.48 & 0.93 & & 0.45 & 30 \\
\hline & $1 \cdot 86$ & $1 \cdot 28$ & & $0 \cdot 58$ & 31 \\
\hline & $2 \cdot 40$ & 1.59 & & 0.81 & 34 \\
\hline & $3 \cdot 21$ & $2 \cdot 02$ & & $1 \cdot 19$ & 37 \\
\hline \multirow{5}{*}{3} & 0.98 & 042 & $0 \cdot 40$ & 0.56 & 57 \\
\hline & $1 \cdot 35$ & 0.65 & 0.61 & $0 \cdot 70$ & 52 \\
\hline & 1.74 & $0 \cdot 86$ & 0.80 & $0 \cdot 88$ & 51 \\
\hline & $2 \cdot 48$ & $1 \cdot 30$ & $1 \cdot 21$ & $1 \cdot 18$ & 48 \\
\hline & $2 \cdot 90$ & $1 \cdot 60$ & $1 \cdot 49$ & $1 \cdot 30$ & 45 \\
\hline \multirow{5}{*}{5} & 1.03 & $0 \cdot 46$ & 0.45 & 0.57 & 55 \\
\hline & $1 \cdot 48$ & $0 \cdot 70$ & 0.66 & 0.78 & 53 \\
\hline & $1 \cdot 86$ & 0.88 & 0.81 & 0.98 & 53 \\
\hline & $2 \cdot 67$ & 1.41 & $1 \cdot 33$ & $1 \cdot 26$ & 47 \\
\hline & $3 \cdot 23$ & 1.71 & $1 \cdot 56$ & $1 \cdot 52$ & 47 \\
\hline \multirow{5}{*}{7} & $1 \cdot 14$ & 0.5 & & 0.64 & 56 \\
\hline & 1.63 & 0.75 & & 0.88 & 54 \\
\hline & 1.99 & 0.94 & & $1 \cdot 05$ & 53 \\
\hline & 2.99 & 1.51 & & $1 \cdot 48$ & 49 \\
\hline & $3 \cdot 47$ & 1.76 & & $1 \cdot 71$ & 49 \\
\hline \multirow{4}{*}{9} & 0.76 & 0.53 & & 0.23 & 30 \\
\hline & 1.27 & 0.81 & & 0.56 & 44 \\
\hline & $2 \cdot 02$ & $1 \cdot 12$ & & 0.90 & 45 \\
\hline & $\begin{array}{l}3 \cdot 42 \\
4 \cdot 20\end{array}$ & $\begin{array}{l}1.65 \\
1.91\end{array}$ & & $\begin{array}{l}1.77 \\
2 \cdot 29\end{array}$ & $\begin{array}{l}52 \\
54\end{array}$ \\
\hline
\end{tabular}

yield the value of $-K_{A}$ and the intercepts on the abscissa yield the value $\mathrm{N}$, the total available number of sites per albumin molecule. Only at concentrations of 3,5 , and $7 \mathrm{~g} / \mathrm{dl}$ of albumin were inverse linear

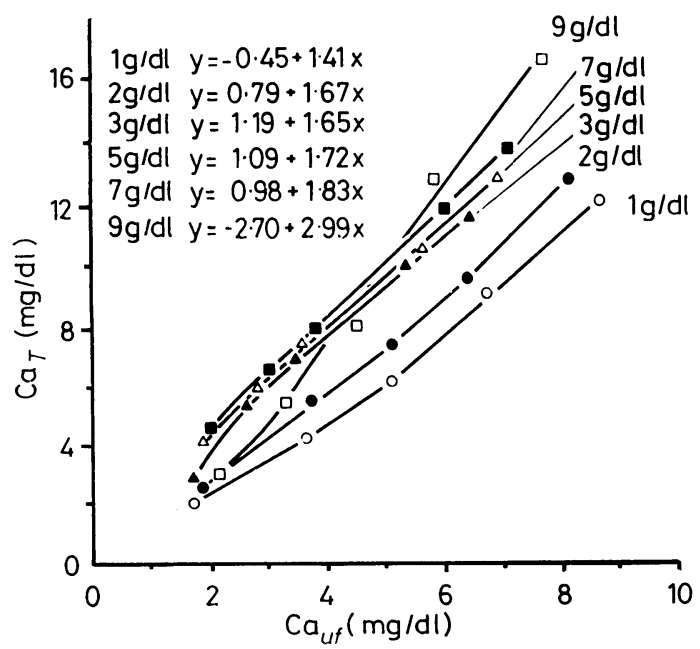

Fig. 1 In vitro relation of total calcium to ultrafilterable calcium at varying bovine serum albumin concentrations (BSA). Linear regressions yielded the equations shown. relations noted and even these showed some curvili near deviation at low $\mathrm{n}$ values. Over the small range of $\mathrm{Ca}^{2+}$ concentrations studied, values for $\mathrm{N}$ were approximately 9,6 , and 3 at 3,5 , and $7 \mathrm{~g} / \mathrm{dl}$ albumin respectively. At both lower and higher albumin concentrations direct positive curvilinear relations were noted. No values for $\mathrm{N}$ were thus obtainable at these concentrations due to anomalous behaviour. The association constants describing the major binding site for calcium obtained from the slopes of

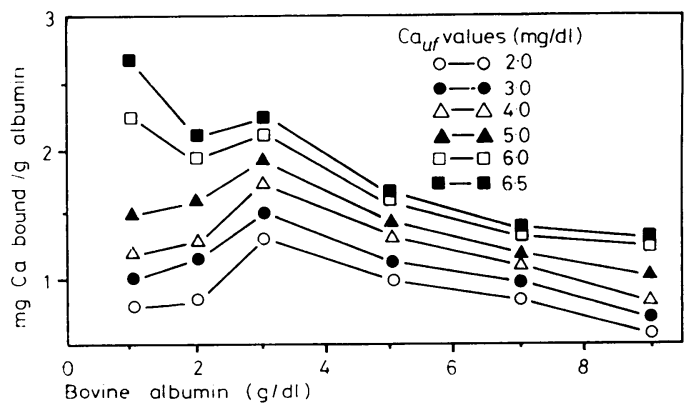

Fig. 2 In vitro binding of calcium to albumin as a function of bovine albumin at constant ultrafilterable calcium concentrations. Data derived from Fig. 1. 


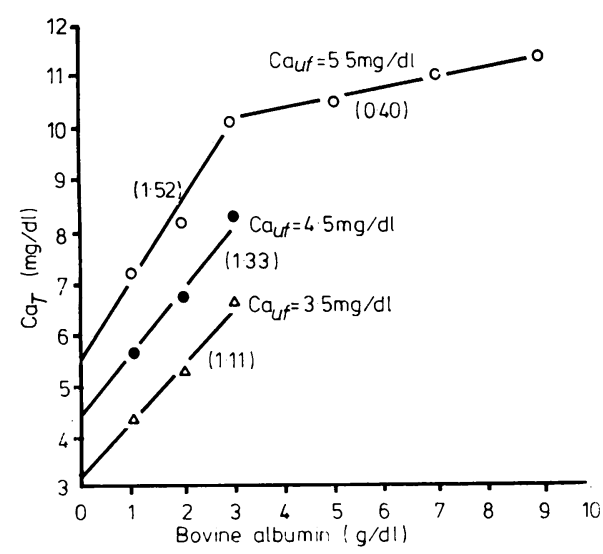

Fig. 3 In vitro relation of total calcium to bovine serum albumin at constant ultrafilterable calcium concentrations of $3 \cdot 5,4 \cdot 5,5 \cdot 5 \mathrm{mg} / \mathrm{dl}$ using linear regressions of data from Fig. I. The slopes of the line are given by the values in parentheses adjacent to each line. At Cauf of $5.5 \mathrm{mg} / \mathrm{dl}$, data were also calculated for $B S A$ concentrations greater than $3 \mathrm{~g} / \mathrm{dl}$. Note the marked change in slope at a BSA concentration of $3 \mathrm{~g} / \mathrm{dl}$.

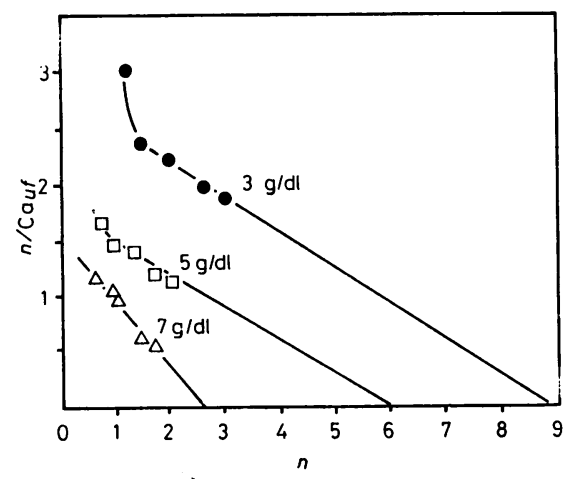

Fig. 4 Scatchard Plot of $n /\left[\mathrm{Ca}^{2+}\right]$ versus $n$ for in vitro binding of $\mathrm{Ca}^{2+}$ to albumin. Nearly linear relations could only be obtained at albumin concentrations of 3, 5, and $7 \mathrm{~g} / \mathrm{dl}$ (concentrations in parentheses adjacent to curves).

the Scatchard plots were $302 \mathrm{l} / \mathrm{mole}\left(\mathrm{pK}_{\mathrm{A}} 2 \cdot 48\right)$ at $5 \mathrm{~g} / \mathrm{dl}$ and $330 \mathrm{l} / \mathrm{mole}\left(\mathrm{pK}_{\mathrm{A}} 2 \cdot 52\right)$ at $3 \mathrm{~g} / \mathrm{dl}$ albumin respectively and were not significantly different from each other. The association constant increased to $550 \mathrm{l} / \mathrm{mole}\left(\mathrm{pK}_{\mathrm{A}} 2.74\right)$ at $7 \mathrm{~g} / \mathrm{dl}$ albumin which was significantly different from the $K_{A}$ values at 3 and $5 \mathrm{~g} / \mathrm{dl}$ albumin. These results indicate that the equilibrium value expressed either as $\mathrm{K}_{\mathrm{A}}$ or $\mathrm{pK} \mathrm{K}_{\mathrm{A}}$ is relatively constant only within the physiological range of albumin and ultrafilterable calcium concentrations.

\section{Discussion}

The interaction of calcium with protein is of considerable physiological and practical importance. In clinical states characterised by changes in protein concentrations, a plethora of formulations have been developed to correct total serum calcium concentrations for changes in protein concentrations. None of these appears to be sufficiently precise to predict the ionised calcium in a given patient with accuracy. ${ }^{18}$ A considerable body of experimental data exists, however, which indicates that binding of calcium to protein is highly complex. Carr ${ }^{12}$ demonstrated more than two decades ago that calcium binding to albumin was not saturable at physiological albumin and $\mathrm{Ca}$ concentrations, that is, total calcium increased with ionised calcium. This relation was linear up to $5 \mathrm{mM} \mathrm{Ca}{ }^{2+}$ and curvilinear at $\mathrm{Ca}^{2+}$ concentrations above $5 \mathrm{mM}$. Similar results were found by Pederson. ${ }^{17}$ Hild and Freeman ${ }^{19}$ noted that the molar binding constant was a curvilinear function of the logarithmic $\mathrm{Ca}^{2+}$ concentration when albumin concentration was maintained constant. Subsequently Niels Fogh-Anderson ${ }^{14}$ noted at least 30 different calcium binding sites on albumin distributed among at least three classes of sites with differing affinity constants for calcium binding to albumin; one of these appeared to be responsible for the major binding of calcium at physiological concentrations of free calcium and normal albumin concentrations. A range of albumin concentrations comparable to those found in clinical situations was not investigated in these studies. Since albumin concentrations may vary widely in clinical disorders, we assessed the effect of such variation in albumin concentrations on calcium binding.

Interpretation and analysis of our data requires awareness of the limitations of the methods used in this study. Firstly ultrafiltration may alter the distribution of calcium among its three components. The total degree of ultrafiltration was therefore kept to less than $5 \%$ of total sample volume. In addition, two consecutive 50 to $100 \mu \mathrm{l}$ samples representing less than $2 \%$ of the retentate volume were obtained just before terminating ultrafiltration and used for calcium analyses. This minimised the effects of concentration of protein in the retentate during ultrafiltration with consequent alterations in bound calcium. Secondly, determination of true $K_{A}$ and $n$ values requires measurement of $\mathrm{Ca}^{2+}$ which was measured in only selected experiments. Caup measures both ionised and chelated calcium. The chelated calcium in these in vitro dialysis studies ranged from 1 to $7 \%$ of total calcium (Table 1) and was lower than the reported in vivo values of 10 to $15 \%$ of total calcium at physiological concentrations 
of $\mathrm{Ca}^{2+}$. Our lower in vitro values were probably due to the high grade purity of the albumin used which was additionally dialysed before and after addition of variable amounts of calcium to the dialysate to remove the chelators citrate and lactate. This was confirmed by direct analysis of the media for these substances at the end of dialyses (fatty acids, however, were only partially removed). Since the difference between ionised and ultrafilterable calcium was within $10 \%$, use of $\mathrm{Cau}_{\text {uf }}$ in place of $\mathrm{Ca}^{2+}$ did not significantly alter the calculation of the values for the association constants (or $\mathrm{pK}_{\mathrm{A}}$ ) derived from Scatchard plots. Using $\mathrm{Ca}_{\text {uf }}$ in the calculations, we obtained pK values of 2.52 and 2.48 at albumin concentrations of 3 and $5 \mathrm{~g} / \mathrm{dl}$ respectively. The pK decreased to 2.47 and 2.42 when $\mathrm{Ca}^{2+}$ was used in the calculations. Our values for pK agree reasonably well with those of Carr ${ }^{12}$ who obtained a pK value of 2.43 at $3 \mathrm{~g} / \mathrm{dl}$ albumin and with those of Weir and Hastings ${ }^{15}$ who obtained an average value of $2 \cdot 20$. The values for the association constant of $\mathrm{pK}_{\mathrm{A}}$ must be interpreted within the limitation imposed by the range of ultrafilterable calciums studied. Binding of a substance to a protein receptor is usually studied over a substance concentration range of one tenth to tenfold the half-saturating concentration. Such a range is not encountered clinically and was not studied. In addition, if more than one class of binding sites is present, a Scatchard plot is curvilinear and the association constants and molar binding ratios values for each class must be determined by curvepeeling techniques. The values for these parameters obained from our studies, therefore, assess only the average influence of such classes of binding sites over the limited concentration range studied. Extrapolation of the curves to the abscissa probably reflects the total molar binding ratio of the predominant calcium binding class and not the true maximal molar binding ratio.

It was not our intent rigorously to evaluate the physical chemistry of calcium-albumin binding, but rather to assess the implications of changes in calcium and albumin concentrations in certain pathophysiological states. Despite the limitations previously enumerated, our in vitro studies reveal three major characteristics of the system which account for certain previously noted observations. Firstly, albumin-bound calcium is directly affected by changes in free calcium concentrations, an effect predictable from the law of mass action. Thus, total calcium should correlate with increasing free calcium concentration because both free and bound calcium concentrations increase. Clinically, the relation of $\mathrm{Ca}_{T}$ on $\mathrm{Ca}_{u f}$ has been noted to be linear over a wide range of albumin and free calcium concentrations. ${ }^{18}$ This results in part from the second characteristic of the system the absence of saturation of binding sites over a range of albumin or free calcium concentrations that are ordinarily encountered even those simulating severe hypoalbuminaemia with co-existing increased ionised calcium. Our studies thus confirm the studies of Carr ${ }^{12}$ at $3 \mathrm{~g} / \mathrm{dl}$ albumin and extend them to both lower and higher albumin concentration.

The absence of calcium binding saturation may account for the phenomenon observed by Rodan and $\mathrm{Katz}^{13}$ who noted a linear relation between $\mathrm{Ca}_{\mathrm{T}}$ and dialysable calcium concentration during in vivo experiments in rats. The dialysable calcium of blood in these experiments was varied by perfusion of rat blood through an extracorporeal dialysis system. These workers proposed that protein-bound calcium could function as a source or sink for ionised calcium. With a marked rise in ionised calcium, part of the increment could be buffered by protein binding. Calcium binding to protein might thus be an important adaptive response in disease states such as hyperparathyroidism, multiple myeloma, or others associated with hypercalcaemia.

Finally, we noted the additional characteristic that albumin bound calcium varied inversely with the absolute albumin concentration. When the binding of calcium to albumin was examined, heterogeneous binding was evident. With increasing albumi concentrations between 3 and $7 \mathrm{~g} / \mathrm{dl}$, the maximune number of moles calcium bound per mole of albumin decreased from 9 to 3 . In the physiological range for albumin of $3-5 \mathrm{~g} / \mathrm{dl}$, the value for the association constant did not change reflecting the predominant effect of one class of binding sites, but increased at the supraphysiological albumin concentration of $7 \mathrm{~g} / \mathrm{dl}$. This increase in the value for the association constant of $7 \mathrm{~g} / \mathrm{dl}$ was associated with a decrease in molar binding ratio. This may reflect the presence of a class of binding sites of higher affinity but lower capacity. Anderson ${ }^{14}$ has described three classes of binding sites; the activity of the third class is detected only at very high concentrations of 8 calcium ( $>10 \mathrm{mM}$ ), a range not investigated in this study. Thus our results are quantitatively and $\mathrm{\rho}$ qualitatively comparable with the results of other investigators when calcium binding was studied at physiological albumin concentrations.

We also noted an additional finding when we of examined calcium binding at albumin concentrations corresponding to hypoalbuminaemic concentrations. In the range of ionised calcium concentrations found in most clinical states, we could not determine unique values for the association constant or for the molar $\stackrel{\varnothing}{\Phi}$ binding ratio. This radical alteration in the character- $\stackrel{\mathcal{P}}{?}$ istics of calcium-albumin binding at simulated 0 hypoalbuminaemic conditions suggests that clinical 
application of formulations with fixed binding ratios to correct $\mathrm{Ca}_{\mathrm{T}}$ for albumin may be particularly inappropriate under such conditions. As shown in Fig. 2, the variability in albumin-bound calcium as a function of $\mathrm{Ca}_{\text {up }}$ was greatest at low albumin concentrations. This could lead to large errors in estimating "corrected" $\mathrm{Ca}_{\mathrm{T}}$ since $\mathrm{Ca}$ uf is usually not known. Clinical studies are needed to investigate this possibility.

This project was supported in part by NIAMD grant AM 19559. We thank J Papaleo, C Gallagher and F Hylan for secretarial assistance.

\section{Conversion of units to SI units}

\begin{tabular}{|c|c|c|c|}
\hline Parameter & $\begin{array}{l}\text { Units used } \\
(w t / v o l)\end{array}$ & Conversion factor & SI units \\
\hline $\begin{array}{l}\text { Albumin (Alb) } \\
\text { Total serum protein (TP) } \\
\text { Globulin } \\
\text { Albumin-bound calcium } \\
\quad \text { (CaAlb) } \\
\text { Protein-bound calcium } \\
\quad(\mathrm{CaPr}) \\
\text { Total calcium }\left(\mathrm{Ca}_{\mathrm{T}}\right) \\
\text { Unfilterable calcium } \\
\text { (Cauf) } \\
\text { Ionised calcium }\left(\mathrm{Ca}^{2+}\right)\end{array}$ & $\begin{array}{l}\mathrm{g} / \mathrm{dl} \\
\mathrm{g} / \mathrm{dl} \\
\mathrm{g} / \mathrm{dl} \\
\mathrm{mg} / \mathrm{dl}\end{array}$ & $\begin{array}{l}\text { Divide by } 6.4 \\
\text { * No constant factor } \\
\text { * No constant factor } \\
\text { Divide by } 4.0\end{array}$ & $\begin{array}{l}\mathrm{mmol} / \mathrm{l} \\
- \\
\mathrm{mmol} / \mathrm{l}\end{array}$ \\
\hline
\end{tabular}

* No constant conversion factor available since globulins and total protein concentrations contain proteins of variable molecular weights.

\section{References}

${ }^{1}$ McLean FC, Hastings AB. The state of calcium in the fluids of the body I. The conditions affecting the ionisation of calcium. J Biol Chem 1935;108:285-322.

${ }^{2}$ Moore EW. Ionised calcium in normal serum, ultrafiltrates, and whole blood determined by ion exchange electrodes. J Clin Invest 1970;49:318-34.

${ }^{3}$ Husdan H, Rapoport A, Locke S, Oreopaulos D. Effect of venous occlusion of the arm on the concentration of calcium in serum and methods for its compensation. Clin Chem 1974;20:529-32.

4 Payne RB, L. Ha AJ, Williams RB, Milner JR. Interpretation of serum calcium in patients with abnormal serum proteins. Br Med J 1973;4:643-6.

${ }^{5}$ Moore EW. Studies with ion exchange calcium electrodes. III. The state of serum calcium in patients with cirrhosis. Gastroenterology 1971;60:43-54.

${ }^{6}$ Husdan H, Rapoport A, Locke S. Influence of posture on the serum concentration of calcium. Metabolism 1973; 22:787-90.

${ }^{7}$ Kelly AL, Munan C, Petitclerk C, Ho PK, Billon B. Use of values for calcium and protein in serum and of a derived index obtained from a probability population sample. Clin Chem 1976;22:1723-6.

${ }^{8}$ Parfitt AM. Correction of plasma calcium concentrations. Br Med J 1971 ; 1 :484-9.

${ }^{9}$ Ljunghall S, Hedstrand H, Hellsing K, Wibell L. Calcium, phosphate and albumin in serum. Acta Med Scand 1977; $201: 23-30$.

${ }^{10}$ Orrell DH. Albumin as an aid in the interpretation of serum calcium. Clin Chim Acta 1971;35:484-9.

${ }^{11}$ Pottgen P, Davis EP. Why measure total serum calcium? Clin Chem 1976;22:1752.

${ }^{12}$ Carr CW. Studies on binding of small ions in protein solutions with the use of membrane electrodes. II. The binding of calcium ions in solutions of bovine serum albumin. Arch Biochem Biophys 1953;43:147-56.

13 Rodan GA, Katz EP. Calcium binding to nondialysable components of rat blood under in vivo conditions. $\mathrm{Am}$ J Physiol 1972;225:1082-8.

14 Anderson NF. Albumin/calcium association at different $\mathrm{pH}$, as determined by potentiometry. Clin Chem $1977 ; 23$ : 2122-6.

${ }^{15}$ Weir EG, Hastings AB. The ionisation constants of calcium proteinate determined by their solubility of calcium carbonate. J Biochem 1936;114:397-406.

${ }^{16}$ Kleeman CR, Massry SG, Colburn JW. The clinical physiology of calcium homeostasis, parathyroid hormone and calcitonin. Calif Med 1971;114:16-43.

17 Pederson KO. Binding of calcium to serum albumin. I. Stoichiometry and intrinsic association constant at physiologic $\mathrm{pH}$, ionic strength and temperature. Scand $J$ Clin Lab Invest 1971;28:459-67.

${ }^{18}$ Ladenson JH, Lewis JW, Boyd JC. Failure of total calcium corrected for protein, albumin and $\mathrm{pH}$ to correctly assess free calcium status. J Clin Endocrinol 1978;46:986-93.

${ }^{19}$ Hild IR, Freeman S. Binding of calcium by human plasma proteins under simulated physiologic conditions. J Appl Physiol 1964;19:292-7.

Requests for reprints to: Dr Anatole Besarab, M.D. Room 1014, College Building, Thomas Jefferson University, 1025 Walnut Street, Philadelphia, PA 19107, USA. 